\title{
Estimation of prostate specific antigen in metabolic syndrome- a study in south Indian male population
}

\author{
Ratnashree Biswas $^{1}$, G.S.R. Kedari ${ }^{2, *}$, Gurupavan Kumar Ganta ${ }^{3}$ \\ ${ }^{1}$ PG Student, ${ }^{2}$ Professor, ${ }^{3}$ Assistant Professor, Dept. of Biochemistry, Saveetha Medical College, Chennai, India
}

*Corresponding Author:

Email: kedari.gsr@gmail.com

\begin{abstract}
Introduction: The main aim of our study was to assess the role of prostate specific antigen in Indian males and to determine its correlation with insulin resistance in metabolic syndrome. Materials and Methods: For this study, 62 male subjects of 40-65 years having metabolic syndrome were selected. Body mass index, fasting blood sugar, serum prostate specific antigen, serum fasting insulin and insulin resistance were analyzed using multivariate regression analysis and Annova test.

Results and Conclusion: There was no statistically significant difference between body mass index and prostate specific antigen, body mass index and insulin resistance, prostate specific antigen and triglyceride, prostate specific antigen and high density lipoprotein, and prostate specific antigen and fasting blood sugar.
\end{abstract}

Keywords: Body mass index, Insulin resistance and Obesity, Prostate specific antigen.

Received: $08^{\text {th }}$ August, 2017

\section{Introduction}

Metabolic syndrome is a cluster of risk factors associated with increased risk of cardiovascular disease and diabetes mellitus. ${ }^{1}$ Metabolic syndrome is present if three or more of the following five criteria are met like- Waist circumference over 40 inches (men), Blood pressure over 130/85 $\mathrm{mmHg}$, Fasting triglyceride (TG) level over $150 \mathrm{mg} / \mathrm{dl}$, highdensity lipoprotein (HDL) cholesterol level less than $40 \mathrm{mg} / \mathrm{dl}$ (men) and Fasting blood sugar over $100 \mathrm{mg} / \mathrm{dl} .^{2}$ The main complication of metabolic syndrome is cardiovascular disease ${ }^{3}$ but there is increased incidence of prostate cancer in these patients. ${ }^{3,4}$ Metabolic syndrome is also associated with other disorders like nonalcoholic fatty liver disease, Polycystic ovarian syndrome, Obstructive sleep apnea, lipodystrophy and micro vascular disease. ${ }^{5}$

Prostate cancer is the most common cancer in elderly patients above 50 years of age in India and worldwide. For the diagnosis of prostate cancer, commonly used parameter for evaluation is prostate specific antigen. Prostate specific antigen (PSA) is a protease that is produced by secretory epithelial cells lining the prostate ducts $^{6}$ in response to androgen receptor activation. Normal levels of PSA in males is < $4 \mathrm{ng} / \mathrm{ml}$. Interactions between body adiposity and steroid hormone metabolism, the inflammatory response, or insulin regulation, are sufficient to affect PSA expression. Prostate specific antigen levels are affected by many factors that may be
Accepted: $19^{\text {th }}$ September, 2017

unrelated to prostate disease, including age and race. $^{7}$ The association between metabolic syndrome and prostate cancer may be due to changes in Insulin and Insulin like growth factorI, Insulin like Growth Factor Binding Proteins, sex hormones like Testosterone and sex hormone binding globulins. ${ }^{4,8}$

Insulin resistance can be defined as a state in which normal amounts of insulin produce a suboptimal biological response. As the degree of insulin resistance increases, impaired glucose tolerance occurs and eventually causes diabetes. ${ }^{9}$ Higher insulin resistance has been observed to contribute to a lower serum PSA concentration, which may lead to delayed prostate cancer diagnosis among individuals with metabolic syndrome. ${ }^{10,11}$ Body mass index (BMI) or Quetelet index is a value derived from weight and height of an individual. It is defined as the body mass divided by the square of the body height, and is universally expressed in units of $\mathrm{kg} / \mathrm{m}^{2} .{ }^{9,12}$ Few studies show association between dermographic and life style characteristics with PSA concentrations in healthy men ${ }^{13}$ and some studies show that age and low BMI are associated with higher PSA levels. ${ }^{14-16}$

As far as our knowledge is concerned, no study has been conducted in Indian males to report an association of metabolic syndrome, insulin resistance with prostate specific antigen levels. The present study is done to evaluate prostate specific antigen, fasting insulin levels, insulin resistance, BMI and lipid profile in metabolic syndrome patients and to study the 
correlation between PSA levels and metabolic syndrome.

\section{Materials and Methods}

The following study was conducted in the Department of Biochemistry and General Medicine of Saveetha Medical College and Hospital. 62 Male subjects of 40-65 years having metabolic syndrome were chosen on the basis of three of the following five criteria like- Waist circumference over 40 inches, Blood pressure over 130/85 mmHg, Fasting triglyceride (TG) level over $150 \mathrm{mg} / \mathrm{dl}$, high-density lipoprotein (HDL) cholesterol level less than $40 \mathrm{mg} / \mathrm{dl}$ (men) and Fasting blood sugar over $100 \mathrm{mg} / \mathrm{dl}$. A detailed clinical history was taken and general examination was done for all these cases. Subjects with medical history of prostatitis and prostate cancer, those having history of prostate surgery or having clinical symptoms of urinary tract infection were excluded from the study.
Individuals with symptomatic ischemic heart disease or symptomatic peripheral neuropathy and those taking any antidiabetic, antihypertensive, antihyperlipedemic drugs were also excluded from the study.

Informed consent was obtained from all the subjects before the procedure. $5 \mathrm{ml}$ of whole blood was collected and samples were processed within 24 hours. Ethical clearance certificate was obtained for the study. The data were analyzed using multivariate regression analysis and Annova test. Fasting blood sugar was measured by Glucose oxidase- Peroxidase method (GODPOD). Serum Prostate Specific Antigen was measured using the chemiluminescent enzyme immunoassay method. Serum fasting insulin was measured using enzyme kit method by automated analyser. Insulin resistance was calculated by Homeostatic model assessment method (HOMA), using formula. ${ }^{11}$ Fasting glucose $(\mathrm{mg} / \mathrm{dl})$ X Fasting Insulin $(\mathrm{mIU} / \mathrm{L})$ 405

\section{Results}

Table 1: Descriptive Statistics

\begin{tabular}{|l|c|c|c|c|c|}
\hline & N & Minimum & Maximum & Mean & $\begin{array}{c}\text { Standard } \\
\text { deviation }\end{array}$ \\
\hline BMI & 62 & 25.20 & 30.80 & 27.2871 & 1.31666 \\
\hline IR (HOMA) & 62 & .22 & 66.67 & 4.0115 & 10.14376 \\
\hline PSA (ng/ml) & 62 & .01 & 7.26 & 2.0525 & 1.72809 \\
\hline TG (mg/dl) & 62 & 54.00 & 326.00 & 169.5645 & 63.68741 \\
\hline HDL (mg/dl) & 62 & 19.00 & 82.00 & 38.1290 & 9.17853 \\
\hline Valid n (list wise) & 62 & & & & \\
\hline
\end{tabular}

Table 2: One Sample Test

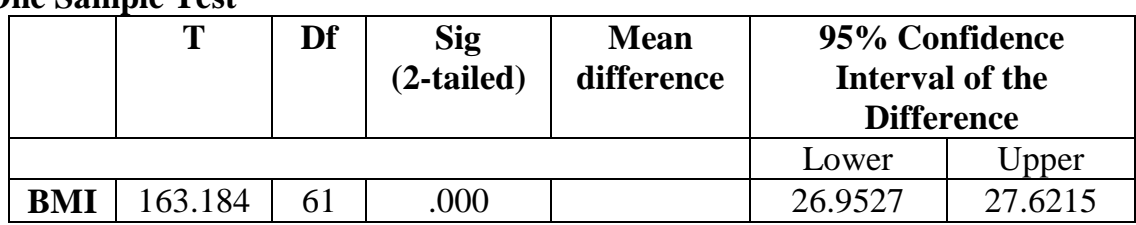

Test value $=0$

Table 3: Statistics

\begin{tabular}{|l|c|c|}
\hline & BMI & IR (HOMA) \\
\hline $\mathrm{n}$ Valid & 62 & 62 \\
\hline Missing & 0 & 0 \\
\hline Mean & 27.2871 & 4.0115 \\
\hline Median & 27.1500 & 1.9900 \\
\hline Standard deviation & 1.31666 & 10.14376 \\
\hline Range & 5.60 & 66.45 \\
\hline Minimum & 25.20 & .22 \\
\hline Maximum & 30.80 & 66.67 \\
\hline
\end{tabular}


Table 4: Correlations

\begin{tabular}{|c|c|c|c|c|c|c|c|c|c|}
\hline & & AGE & $\begin{array}{c}\text { FBS } \\
(\mathrm{mg} / \mathrm{dl})\end{array}$ & $\begin{array}{c}\mathbf{T G} \\
(\mathrm{mg} / \mathrm{dl})\end{array}$ & $\begin{array}{c}\text { HDL } \\
\text { (mg/dl) }\end{array}$ & $\begin{array}{c}\text { Insulin } \\
\text { (Miu/ml) }\end{array}$ & $\begin{array}{c}\mathrm{WC} \\
\text { (cms) }\end{array}$ & BMI & $\begin{array}{c}\text { IR } \\
\text { (Homa) }\end{array}$ \\
\hline \multirow[t]{3}{*}{ AGE } & $\begin{array}{l}\text { Pearson } \\
\text { correlatio } \\
\mathrm{n}\end{array}$ & 1 & -.237 & -.054 & -.037 & -.073 & -.196 & -.044 & -.087 \\
\hline & $\begin{array}{l}\text { Sig. } \\
\text { (2-tailed) }\end{array}$ & & .064 & .675 & .775 & .575 & .126 & .735 & .502 \\
\hline & $\mathrm{n}$ & 62 & 62 & 62 & 62 & 62 & 62 & 62 & 62 \\
\hline \multirow[t]{3}{*}{$\begin{array}{l}\text { FBS } \\
\text { (mg/dl) }\end{array}$} & $\begin{array}{l}\text { Pearson } \\
\text { correlatio } \\
\mathrm{n}\end{array}$ & -.237 & 1 & .002 & $.250 *$ & .049 & $.251 *$ & .099 & .123 \\
\hline & $\begin{array}{l}\text { Sig. } \\
\text { (2-tailed) }\end{array}$ & .064 & & .990 & .050 & .705 & .049 & .443 & .340 \\
\hline & $\mathrm{n}$ & 62 & 62 & 62 & 62 & 62 & 62 & 62 & 62 \\
\hline \multirow[t]{3}{*}{$\begin{array}{l}\text { TG } \\
(\mathrm{mg} / \mathrm{dl})\end{array}$} & $\begin{array}{l}\text { Pearson } \\
\text { correlatio } \\
\mathrm{n}\end{array}$ & -.054 & .002 & 1 & -.035 & -.080 & -.125 & -.086 & -.077 \\
\hline & $\begin{array}{l}\text { Sig. } \\
\text { (2-tailed) }\end{array}$ & .675 & .990 & & .787 & .536 & .333 & .509 & .553 \\
\hline & $\mathrm{n}$ & 62 & 62 & 62 & 62 & 62 & 62 & 62 & 62 \\
\hline \multirow[t]{3}{*}{$\begin{array}{l}\text { HDL } \\
\text { (mg/dl) }\end{array}$} & $\begin{array}{l}\text { Pearson } \\
\text { correlatio } \\
\mathrm{n}\end{array}$ & -.037 & $.250 *$ & -.035 & 1 & .155 & .072 & -.111 & .158 \\
\hline & $\begin{array}{l}\text { Sig. } \\
\text { (2-tailed) }\end{array}$ & .775 & .050 & .787 & & .228 & .580 & .392 & .219 \\
\hline & $\mathrm{n}$ & 62 & 62 & 62 & 62 & 62 & 62 & 62 & 62 \\
\hline \multirow[t]{3}{*}{$\begin{array}{l}\text { Insulin } \\
(\mathrm{Miu} / \mathrm{ml})\end{array}$} & $\begin{array}{l}\text { Pearson } \\
\text { correlatio } \\
\mathrm{n}\end{array}$ & -.073 & .049 & -.080 & .155 & 1 & .155 & .070 & $.991 * *$ \\
\hline & $\begin{array}{l}\text { Sig. } \\
\text { (2-tailed) }\end{array}$ & .575 & .705 & .536 & .228 & & .230 & .591 & .000 \\
\hline & $\mathrm{n}$ & 62 & 62 & 62 & 62 & 62 & 62 & 62 & 62 \\
\hline \multirow[t]{3}{*}{$\begin{array}{l}\text { WC } \\
(\mathrm{cms})\end{array}$} & $\begin{array}{l}\text { Pearson } \\
\text { correlatio } \\
\mathrm{n}\end{array}$ & -.196 & $.251 *$ & -.125 & .072 & .155 & 1 & $.297 *$ & .153 \\
\hline & $\begin{array}{l}\text { Sig. } \\
\text { (2-tailed) }\end{array}$ & .126 & .049 & .333 & .580 & .230 & & .019 & .234 \\
\hline & $\mathrm{n}$ & 62 & 62 & 62 & 62 & 62 & 62 & 62 & 62 \\
\hline \multirow[t]{3}{*}{ BMI } & $\begin{array}{l}\text { Pearson } \\
\text { correlatio } \\
\mathrm{n}\end{array}$ & -.044 & .099 & -.086 & -.111 & .070 & $297 *$ & 1 & .083 \\
\hline & $\begin{array}{l}\text { Sig. } \\
\text { (2-tailed) }\end{array}$ & .735 & .443 & .509 & .392 & .591 & .019 & & .520 \\
\hline & $\mathrm{n}$ & 62 & 62 & 62 & 62 & 62 & 62 & 62 & 62 \\
\hline \multirow[t]{3}{*}{$\begin{array}{l}\text { IR } \\
\text { (HOMA) }\end{array}$} & $\begin{array}{l}\text { Pearson } \\
\text { correlatio } \\
\mathrm{n}\end{array}$ & -.087 & .123 & -.077 & .158 & $.991 * *$ & .153 & .083 & 1 \\
\hline & $\begin{array}{l}\text { Sig. } \\
\text { (2-tailed) }\end{array}$ & .502 & .340 & .553 & .219 & .000 & .234 & .520 & \\
\hline & $\mathrm{n}$ & 62 & 62 & 62 & 62 & 62 & 62 & 62 & 62 \\
\hline
\end{tabular}

*. Correlation is significant at the 0.05 level (2-tailed).

**. Correlation is significant at the 0.01 level (2-tailed).

Table 5: Annova

\begin{tabular}{|l|l|c|c|c|c|c|}
\hline & & $\begin{array}{c}\text { Sum of } \\
\text { squares }\end{array}$ & df & Mean square & F & Sig. \\
\hline \multirow{2}{*}{ AGE } & Between groups & 3569.935 & 60 & 59.499 & 7.437 & .285 \\
\cline { 2 - 7 } & Within groups & 8.000 & 1 & 8.000 & & \\
\cline { 2 - 7 } & Total & 3577.935 & 61 & & & .377 \\
\hline \multirow{2}{*}{ FBS } & Between groups & 182336.419 & 60 & 3038.940 & .891 \\
\hline
\end{tabular}




\begin{tabular}{|c|c|c|c|c|c|c|}
\hline \multirow{2}{*}{$(\mathrm{mg} / \mathrm{dl})$} & Within groups & 8064.500 & 1 & 8064.500 & & \\
\hline & Total & 190400.919 & 61 & & & \\
\hline \multirow{3}{*}{$\begin{array}{l}\text { TG } \\
(\mathrm{mg} / \mathrm{dl})\end{array}$} & Between groups & 245621.242 & 60 & 4093.687 & 2.274 & .490 \\
\hline & Within groups & 1800.000 & 1 & 1800.000 & & \\
\hline & Total & 247421.242 & 61 & & & \\
\hline \multirow[t]{3}{*}{ HDL (mg/dl) } & Between groups & 5054.468 & 60 & 84.241 & .997 & .679 \\
\hline & Within groups & 84.500 & 1 & 84.500 & & \\
\hline & Total & 5138.968 & 61 & & & \\
\hline \multirow{3}{*}{$\begin{array}{l}\text { INSULIN(mIU } \\
\text { /ml) }\end{array}$} & Between groups & 30973.582 & 60 & 516.226 & 46.738 & .116 \\
\hline & Within groups & 11.045 & 1 & 11.045 & & \\
\hline & Total & 30984.627 & 61 & & & \\
\hline \multirow[t]{3}{*}{$\mathrm{WC}(\mathrm{cms})$} & Between groups & 715.935 & 60 & 11.932 & .663 & .776 \\
\hline & Within groups & 18.000 & 1 & 18.000 & & \\
\hline & Total & 733.935 & 61 & & & \\
\hline \multirow[t]{3}{*}{ BMI } & Between groups & 103.330 & 60 & 1.722 & .712 & .759 \\
\hline & Within groups & 2.420 & 1 & 2.420 & & \\
\hline & Total & 105.750 & 61 & & & \\
\hline \multirow[t]{3}{*}{ IR (HOMA) } & Between groups & 6275.676 & 60 & 104.595 & 108.270 & .076 \\
\hline & Within groups & .966 & 1 & .966 & & \\
\hline & Total & 6276.642 & 61 & & & \\
\hline
\end{tabular}

\section{Discussion}

The mean and standard deviation of body mass index of the subjects is 27.2871 and 1.31666 , for insulin resistance is 4.0115 and 10.14376 , for prostate specific antigen is 2.0525 and 1.72809 , for triglyceride is 169.5645 and 63.68741, for high density lipoprotein is 38.1290 and 9.17853 respectively. The $95 \%$ confidence interval of the difference for BMI by one sample test is 26.9527 (lower) and 27.6215 (upper).Table 4 shows the correlations of different parameters with each other. Table 5 shows the level of significance of different parameters by ANNOVA test.

In the present study, which was conducted in south Indian male population, we did not observe any statistical significant difference between body mass index and insulin resistance, body mass index and prostate specific antigen. There was no statistical significant difference between the various parameters like age, fasting blood sugar, triglyceride, high density lipoprotein and insulin levels. Our study supports the studies, which showed that there is no statistical significant difference between body mass index and prostate specific antigen levels. ${ }^{17-19}$ But some studies have showed that body mass index is inversely associated with prostate specific antigen levels. ${ }^{20,21}$

Few studies suggested that metabolic syndrome was not associated with prostate specific antigen levels in a screened population and this lack of association may reflect the heterogeneous relationship between each metabolic risk factor and serum prostate specific antigen. ${ }^{22}$ In men, obesity is associated with lower testosterone and sex hormone binding globulin and higher estrogen blood concentrations $^{23,24}$ and these endocrine differences may affect the production of prostate specific antigen. ${ }^{25}$ Central obesity leads to insulin resistance. ${ }^{26}$ Adipose tissue secretes Adipocytokines and these substances can induce insulin resistance..$^{27}$ The serum prostate specific antigen level may be influenced by many factors such as age, BMI, prostate volume and prostate disease. ${ }^{19,28}$ Some studies reported negative association between BMI, HDL and fasting blood glucose with serum PSA levels. ${ }^{29}$ Whereas few studies demonstrated that patients with central obesity, high systolic blood pressure by diastolic blood pressure, high triglyceride, low HDL-C and high fasting blood glucose had a significantly higher serum prostate specific antigen levels than in patients without these conditions. ${ }^{27}$

The main limitation of our study is that fewer subjects of metabolic syndrome were included. The subjects were all healthy. In our study, prostate weight and volumes of the subjects were not measured, which will affect the prostate specific antigen levels. Even prostate biopsy was not done to exclude prostate cancer. So, further studies are required to show which component of metabolic syndrome is more associated with serum prostate specific antigen levels.

\section{Acknowledgements}

We sincerely thank my parents, Dr. Gayatri Biswas and Mr. Biswanath Biswas, for their 
continuous help and support given through the entire study. We also extend our sincere thanks to all the authors where the literature for this manuscript has been cited and discussed.

\section{Conflict of Interest \\ Declared none}

\section{Compliance with Ethical Standards Nil}

\section{References}

1. Aaron J. Tande, Elizabeth A. Platz and Aaron R. Folsom. The Metabolic Syndrome is associated with reduced risk of prostate cancer. Am J Epidemiol 2006;164:1094-102

2. Jari A. Laukkanen, David E. Laaksonen, Leo Niskanen et al. Metabolic syndrome and the risk of prostate cancer in Finish men: A population based study. Cancer Epidemiol Biomarkers Prev 2004; 13 (10) October 2004:1646-50

3. Lakka HM, Laaksonen DE, Lakka TA, et al. The metabolic syndrome and total cardiovascular disease mortality in middle-aged men. JAMA 2002;288:2709-16

4. Barnard RJ, Aronson WJ, Tymchuk CN, et al. Prostate cancer: another aspect of the insulinresistance syndrome? Obes Rev 2002;3:303-8

5. Cornier MA, Dabelea D, Hernandez TL et al. The metabolic syndrome. Endocr Rev 2008;29:777822

6. Sirovich BE, Schwartz LM, Woloshin S. Screening men for prostate and colorectal cancer in the United States. JAMA 2005;289:1414-20

7. Mariko Naito, YatamiAsai, Atsuyoshi Mori et al. Association of obesity and diabetes with serum prostate specific antigen levels in Japanese males. Nagoya J. Med. Sci;2012;74. 285-92

8. Smith GD, Gunnell D, Holly J. Cancer and insulin-like growth factor-1. A potential mechanism linking the environment with cancer risk. BMJ 2000;321:847-8

9. June Hyun Han, Yong Taec Lee, Kyung Won Kwak, et al. Relationship between insulin resistance, obesity and serum prostate specific antigen levels in healthy men. Asian Journal of Andrology (2010) 12:400-4

10. Müller $\mathrm{H}$

, Raum E, Rothenbacher D, Stegmaier C, Brenner $\mathrm{H}$; Association of diabetes and body mass index with levels of prostate specific antigen: implications for correction of prostate specific antigen cutoff values? Cancer Epidemiology Biomarkers Prevention, 2009 May;18(5):1350-6

11. AS Parker, DD Thiel, E Bergstralh, RE Carlson, LJ Rangel, RW Joseph, N Diehl and RJ Karnes; Obese men have more advanced and more aggressive prostate cancer at the time of surgery than non-obese men after adjusting for screening PSA level and age: results from two independent nested case-control studies. Prostate cancer and prostatic disease (2013)16,352-6

12. Alaa lrifai, Ahmed Ouad, Sharaki, Mohamed Abdelhady; Correlation of body mass index with serum total PSA, total testosterone and prostatic volume in a sample of men. Polish Annals of Medicine, Volume23, Issue 1, February 2016, pages 1-5

13. Alan R. Kristal, Chen Chi, Catherine M. Tangen et al. Association of Dermographic and lifestyle characteristics with prostate specific antigen concentration and rate of PSA increase. Cancer 2006, volume 106(2);320-8

14. De Antoni EP, Crawford ED, Oesterling JE, et al. Age and race-specific reference ranges for prostate specific antigen from a large communitybased study. Urology 1996;48:234-9

15. Henderson RJ, Eastham JA, Culkin DJ, et al. Prostate specific antigen (PSA) and PSA density: racial differences in men without prostate cancer. J Natl Cancer Inst 1997;89:134-8

16. Ku JH, Kim ME, Lee NK, Park YH, Ahn Jo. Influence of age, anthropometry and hepatic and renal function on serum prostate-specific antigen levels in healthy middle-age men. Urology 2003;61:132-6

17. Hutterer G, Perrotte P, Gallina A et al. Body mass index does not predict prostate-specific antigen or percent free prostate-specific antigen in men undergoing prostate cancer screening. Eur $\mathbf{J}$ Cancer, 2007;43:1180-7

18. Thompson IM, Leach R, Troyer D et al. Relationsip of body mass index and prostate specific antigen in a population based study. Urol Oncol,2004;22:127-31

19. Kristal AR, Chi C, Tangen CM et al. Associations of dermographic and lifestyle characteristics with prostate specific antigen concentration and rate of PSA increase. Cancer, 2006;106:320-8

20. Chan IH, Ahn SH, Han JH et al. The clinical significance in healthy men of the association between obesity related plasma hemodilution and tumor marker concentration. J Urol, 2009;181:567-72

21. Ando R, Nagaya T, Hashimoto $Y$, et al. Inverse relationsip between obesity and serum prostate specific antigen level in healthy Japanese men: a hospital based cross sectional survey, 2004-2006. Urology, 2008;72:561-5

22. In Gab Jeong, Seung Sik Hwang, Hong Kyu Kim, Hanjong Ahn, and Choung- Soo Kim. The association of metabolic syndrome and its components with serum prostate specific antigen levels in a Korean- screened population, Cancer Epidemiol Biomarkers Prev; 2010:19(2):371-80

23. Gapstur SM, Gann PH, Kopp P, Colangelo L, Longcope C, Liu K. Serum androgen concentrations in young men: a longitudinal analysis of associations with age, obesity and race. The Cardia male hormone study. Cancer Epidemiol Biomarkers Prev. 2002;11:1041-7

24. Farnsworth WE. Estrogen in the etiopathogenesis of BPH. Prostate. 1999;41:263-74

25. Young CY-F, Montgomery BT, Andrews PE et al. Hormone regulation of prostate specific antigen messenger RNA in human prostatic adenocarcinoma cell line LNCaP. Cancer Res. 1991;51:3748-52.

26. Giovanucci E, Rimm EB, Chute CG et al. Obesity and benign prostatic hyperplasia. Am J Epidemiol 1994;140:989-1002

27. Hyun Keun Byun, Yun Hsien Sung, Non Kim et al. Relationship between prostate specific antigen, 
prostate volume and components of metabolic syndrome in healthy Korean me. Korean J Urol 2012;53:774-8

28. Bailargeon J, Pollock BH, Kristal AR et al. The association of body mass index and prostate specific antigen in a population-based study. Cancer 2005; 103:1092-5

29. Han JH, Chang IH, Ahn SH et al. Association between serum prostate specific antigen level, liver function test and lipid profile in healthy men. BJU Int 2008;102:1097-101 